\title{
Study Mechanism of Dispute Caused by Engineering Project risk Based on the Theory of Contracts Status
}

\author{
Yilin Yin ${ }^{1,2}$, Huashan Wang ${ }^{1,}$ a \\ ${ }^{1}$ School of Management, Tianjin University of Technology, Tianjin 300384, China \\ ${ }^{2}$ School of Management, Tianjin University, Tianjin 300072, China \\ ashantjlg@163.com
}

\begin{abstract}
The paper creates the state model of the contract based on the model of GHM in theory of property. By analyzing the model, this study elaborates two key issues .The first key issue is to identify risk factors and divide responsibility.The second issue is to identify critical control point of contracts state compensation. This paper identified twenty-two risk factors that could change the state of contract, and found critical control point of contracts state compensation in both cases. This conclusion provides theoretic support for guarding against dispute in the future.
\end{abstract}

Keywords: Engineering project; Contracts state; Risk factors; Status compensation.

\section{Introduction}

Risk of construction project is a collection that affect the project goals. At the same time, it also has many characteristics, such as objective integrity and random [1]. In the engineering practice, description of the risk is very fuzzy, and confirming it is very difficult.so incomplete contract is inevitable [2]. Fuzzy convention lefts behind potential dangers for disputes.

The contract states is a kind of prediction about future development. It reflects parties' pursuit of profits in the project contract. No matter whether contractor and employer aware of the existence of incomplete contract, engineering project risk can make the target deviation. There will be a dispute between the parties to a contract, and the contract state will not be balance. Nowadays, project investment scale is bigger and bigger, and relationship of parties is more complicated, Project dispute appeared more easily [3]

By the above analysis may safely draw the conclusion that risk is the key factor inducing project dispute in the incomplete contract. The contract status can reflect the risk's influence on the relationship between the parties. It is the external form of contract disputes. However, the study of relationship between risk caused disputes is not enough. And many people just builded the contract state model on the basis of summarizing the practical experience.so this article will build the new contract state model according to the GHM theory. Explain the form of the project risk factors, and the key control points in the process of state compensation. Meanwhile, this article will put forward reasonable suggestions of prevention project dispute.

\section{Literature Review}

\section{1 contract status}

Engineering contract status is a collection about division of responsibility, contract price, construction period and construction scheme. It also includes the role of the relationship between the parties to the contract. It will show the different status as the change of time. Yang Liming state the contract as a function of all the elements including quantities, construction condition, construction scheme, project price and so on. He thought that the contract status, including the state of ideal and reality [4]. Li Xiaolong thought that the contract status, including the initial state, ideal state, actual state and target state. He believed that the contract target will continue to change with the emergence of risk factors. and the contract by the ideal into reality [5]. Currently, some scholars think, including Wang Jianyun, that contract including primitive state, imaginary state and actual state [6]

By combing literature, although the researchers have different point about dividing the contract status, they have the same understanding about the nature of the change. It is said that the contract 
status changing is always exist in the presence of uncertain risk factors. The article is based on the understanding to carry out the following research.

\section{2 the Contract State Model}

Contract status change is the external manifestation of the dispute, the importance of building contract state model would have got the researchers attention. Li Kun considered that interruptions cause changes in the state of contract in his contract state model. He came to the conclusion when studied interference factors in FIDIC contract conditions. All at once, he thought that adjustment is a kind of path to make the contract to return reality [7]. Qiu Yan also created contract status models based on the study of the forecast change. She thought construction scheme is very important in the process of contract state changes. and engineering change is a better way to adjust the contract status.

Through the analysis, although researchers attempting to deal with engineering contract relationship through analyzing the state model of the contract, the game relationship between contracting parties is not clear. So, as a result, this article will rebuild project contract state model to illustrate internal mechanism.

\subsection{The Contract State Model Based on the GHM}

GHM theory thought: human thinking is limited, and there are predicted cost, contract cost and executive cost, people can only sign an incomplete contract [8]. And people pursue to maximize output and investment incentives exclusiveness, so no-cost Kos renegotiate is inevitable after things happen. By analyzing the GHM theory, it has obvious advantages in explain relationship between the parties to the contract and describe the contract status. On this basis, this paper builds the state model of the contract in the situation of the project microscopically. In this model, the contract includes three changes state, 0 phase of the contract - the initial state, 1 phase of the contract - the state of nature, 2 phase of the contract - the state of end.

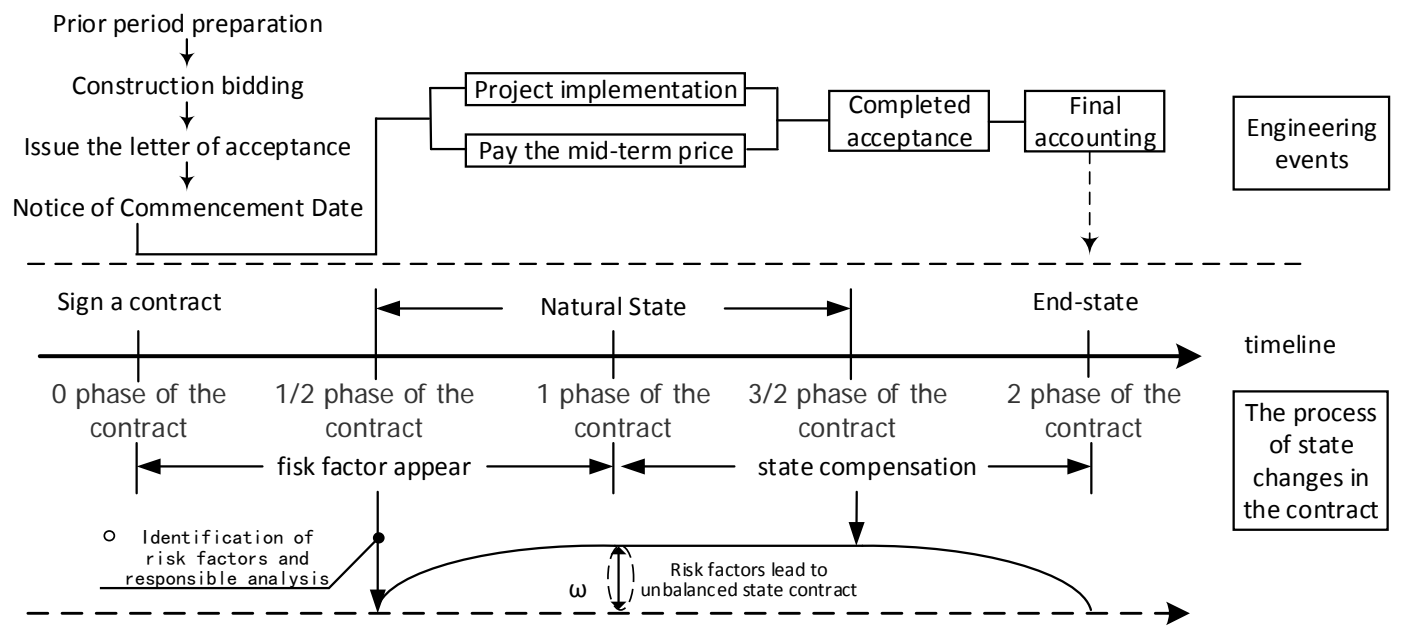

Figure 1 the project contract state model

Project contract state phase begins with 0 , It is the time to sign a contract. In this stage, contracting parties should complete the preparation, bidding and signing contract. There is a game relation between the parties to the contract in the o phase of the contract. In this kind of relationship, the developer distribute more risk to the contractor, bear the liability for less. And the contractor undertakes projects in the case of unfair. Finally, it form project contract price that the core content in 0 phase of the contract. Because there is no fully identified risk factors and risk sharing is not reasonable, contract disputes is inevitable.

In the 1 phase of the contract, Engineering external risk appear constantly, and the contract become out of balance. At this stage, the contractor to carry out the project work, the developer pay the progress payment in accordance with the contract. Because the environment has been changed, contracting parties unable to perform the content of the original contract, there will be a new game relation between the parties to the contract. The contractor cannot get expected yield, and sinks into the predicament of change between opportunistic and behave [9]. Although the developer realizes that contractors may choose opportunism behavior, the urgent needs of the project make him sink into the lock-in dilemma. Contract status change is the key to this process, and it will affect the project 
completion settlement. To illustrate the effects of risk factors and compensation of contract state, this contract state model set $1 / 2$ phase of the contract and $3 / 2$ phase of the contract. They reflect the state change of time nodes.

From what has been discussed above, risk factors could make the contract state imbalance, and induce project dispute. In the process of state compensation contract, opportunism behavior will also induce project dispute. While the causal relationship has been made clear, the forms of risk factors and the key point of compensation contract is not clear.so this article will explain the two key problems.

\section{Identification of Risk Factors and Imputation}

In order to improve the accuracy and completeness in the process of identifying risk factors, This paper analyzed the 《Standard construction of the tender documents》 and 《The project construction contract (model text)》.

Table 1 Collection of risk factors induced dispute

\begin{tabular}{|c|c|c|c|c|c|c|c|}
\hline \multirow{3}{*}{$\begin{array}{l}\text { form of the } \\
\text { risk }\end{array}$} & \multirow{3}{*}{ risk factors } & \multirow{3}{*}{$\begin{array}{l}\text { order } \\
\text { numbe } \\
\mathrm{r}\left(R_{i}\right)\end{array}$} & \multicolumn{2}{|c|}{ document name } & \multicolumn{3}{|c|}{ the subjects of liability } \\
\hline & & & \multirow{2}{*}{$\begin{array}{l}\text { 《Standard } \\
\text { construction of the } \\
\text { tender documents》 }\end{array}$} & \multirow{2}{*}{$\begin{array}{c}\text { 《The project } \\
\text { construction } \\
\text { contract(model text }) 》\end{array}$} & \multicolumn{2}{|c|}{$\begin{array}{l}\text { The employer } \\
\text { responsibility }\end{array}$} & \multirow{2}{*}{$\begin{array}{c}\text { The } \\
\text { contractor } \\
\text { responsibi- } \\
\text { lity }\end{array}$} \\
\hline & & & & & interior & external & \\
\hline $\begin{array}{c}\text { Legal } \\
\text { environmen } \\
\text { t risk }\end{array}$ & $\begin{array}{l}\text { Changes in laws } \\
\text { and regulations }\end{array}$ & $R_{1}$ & $\begin{array}{l}\text { 16.2 Legal changes } \\
\text { lead to price } \\
\text { adjustment }\end{array}$ & $\begin{array}{l}\text { 11.2 Legal changes lead } \\
\text { to price adjustment }\end{array}$ & & $\sqrt{ }$ & \\
\hline \multirow{5}{*}{$\begin{array}{l}\text { Natural } \\
\text { environmen } \\
\text { tal risk }\end{array}$} & Cultural relics & $R_{2}$ & 1.10 Fossil relics & 1.9 Fossil relics & & $\sqrt{ }$ & \\
\hline & $\begin{array}{l}\text { Special material } \\
\text { conditions }\end{array}$ & $R_{3}$ & $\begin{array}{l}\text { 4.11 Special material } \\
\text { conditions }\end{array}$ & $\begin{array}{l}\text { 7.6 Special material } \\
\text { conditions }\end{array}$ & & $\sqrt{ }$ & \\
\hline & $\begin{array}{l}\text { Special climate } \\
\text { environment }\end{array}$ & $R_{4}$ & $\begin{array}{l}\text { 11.4 Special climate } \\
\text { environment }\end{array}$ & $\begin{array}{l}\text { 7.7 Special climate } \\
\text { environment }\end{array}$ & & $\sqrt{ }$ & \\
\hline & Natural disasters & $R_{5}$ & $\begin{array}{c}21.3 \text { The consequences } \\
\text { of force majeure and its } \\
\text { processing }\end{array}$ & $\begin{array}{l}\text { 17.1 The confirmation of } \\
\text { force majeure }\end{array}$ & & $\sqrt{ }$ & $\sqrt{ }$ \\
\hline & $\begin{array}{l}\text { The force majeure } \\
\text { for the delay }\end{array}$ & $R_{6}$ & $\begin{array}{l}\text { 21.3.2 The force } \\
\text { majeure for the delay }\end{array}$ & $\begin{array}{l}\text { 17.3 Consequences of } \\
\text { force majeure }\end{array}$ & & $\sqrt{ }$ & $\sqrt{ }$ \\
\hline $\begin{array}{l}\text { The } \\
\text { political } \\
\text { environmen } \\
\text { t risk } \\
\end{array}$ & Social Emergency & $R_{7}$ & $\begin{array}{l}21.3 \text { The consequences } \\
\text { of force majeure and its } \\
\text { processing }\end{array}$ & $\begin{array}{l}\text { 17.1 The confirmation of } \\
\text { force majeure }\end{array}$ & & $\sqrt{ }$ & $\sqrt{ }$ \\
\hline $\begin{array}{c}\text { The } \\
\text { economic } \\
\text { environmen } \\
\text { t risk }\end{array}$ & Price fluctuation & $R_{8}$ & $\begin{array}{l}\text { 16.1 Price fluctuations } \\
\text { caused by price } \\
\text { adjustment }\end{array}$ & $\begin{array}{c}11.1 \text { Market price } \\
\text { fluctuations caused by the } \\
\text { adjustment }\end{array}$ & & $\sqrt{ }$ & $\sqrt{ }$ \\
\hline \multirow{6}{*}{$\begin{array}{l}\text { Contract } \\
\text { compliance } \\
\text { risk }\end{array}$} & $\begin{array}{l}\text { The accuracy of } \\
\text { the survey data }\end{array}$ & $R_{9}$ & $\begin{array}{c}\text { 4.10 The contractor site } \\
\text { survey }\end{array}$ & $\begin{array}{c}\text { 2.4.2 Provide the } \\
\text { construction conditions } \\
\text { 3.4 The contractor field } \\
\text { exploration }\end{array}$ & & & $\sqrt{ }$ \\
\hline & $\begin{array}{l}\text { The contractor } \\
\text { materials and } \\
\text { engineering } \\
\text { equipment or } \\
\text { engineering } \\
\text { accidents caused } \\
\text { purchasing } \\
\text { schedule delays }\end{array}$ & $R_{10}$ & $\begin{array}{l}5.1 \text { Materials provided } \\
\text { by the contractor and } \\
\text { engineering equipment }\end{array}$ & $\begin{array}{l}8.2 \text { The contractor } \\
\text { purchasing materials and } \\
\text { engineering equipment }\end{array}$ & & & $\sqrt{ }$ \\
\hline & $\begin{array}{l}\text { The contractor to } \\
\text { cover }\end{array}$ & $R_{11}$ & $\begin{array}{l}\text { 13.5.3 The contractor } \\
\text { to cover }\end{array}$ & $\begin{array}{l}\text { 5.3.4 The contractor to } \\
\text { cover }\end{array}$ & & & $\sqrt{ }$ \\
\hline & $\begin{array}{c}\text { Delays of not } \\
\text { finishing the work } \\
\text { by the agreement } \\
\text { creates }\end{array}$ & $R_{12}$ & $\begin{array}{l}11.5 \text { The contractor } \\
\text { delays }\end{array}$ & $\begin{array}{c}\text { 7.5.2 The contractor } \\
\text { delays }\end{array}$ & & & $\sqrt{ }$ \\
\hline & $\begin{array}{l}\text { The contractor to } \\
\text { suspend } \\
\text { construction } \\
\text { causes }\end{array}$ & $R_{13}$ & $\begin{array}{l}12.1 \text { The contractor to } \\
\text { suspend construction } \\
\text { responsibility }\end{array}$ & $\begin{array}{l}\text { 7.8.2 The cause to } \\
\text { suspend construction } \\
\text { contractor }\end{array}$ & & & $\sqrt{ }$ \\
\hline & $\begin{array}{l}\text { Suspended after } \\
\text { construction delay } \\
\text { or refused to } \\
\text { return to work }\end{array}$ & $R_{14}$ & $\begin{array}{l}\text { 12.4 Return to work } \\
\text { after suspension of the } \\
\text { construction }\end{array}$ & $\begin{array}{l}\text { 7.8.5 Return to work after } \\
\text { suspension of the } \\
\text { construction }\end{array}$ & & & $\sqrt{ }$ \\
\hline
\end{tabular}




\begin{tabular}{|c|c|c|c|c|c|c|c|}
\hline \multirow{10}{*}{$\begin{array}{l}\text { form of the } \\
\text { risk }\end{array}$} & \multirow{3}{*}{ risk factors } & \multirow{3}{*}{$\begin{array}{c}\text { order } \\
\text { numbe } \\
\mathrm{r}\left(R_{i}\right)\end{array}$} & \multicolumn{2}{|c|}{ document name } & \multicolumn{3}{|c|}{ the subjects of liability } \\
\hline & & & \multirow{2}{*}{$\begin{array}{l}\text { 《Standard } \\
\text { construction of the } \\
\text { tender documents》 }\end{array}$} & \multirow{2}{*}{$\begin{array}{c}\langle\text { The project } \\
\text { construction } \\
\operatorname{contract}(\text { model text })\rangle\end{array}$} & \multicolumn{2}{|c|}{$\begin{array}{l}\text { The employer } \\
\text { responsibility }\end{array}$} & \multirow{2}{*}{$\begin{array}{l}\text { The } \\
\text { contractor } \\
\text { responsibi- } \\
\text { lity }\end{array}$} \\
\hline & & & & & interior & external & \\
\hline & $\begin{array}{c}\text { Materials, } \\
\text { equipment and } \\
\text { engineering test } \\
\text { and inspection is } \\
\text { not in conformity } \\
\text { with the } \\
\text { requirements }\end{array}$ & $R_{15}$ & $\begin{array}{l}\text { 13.1 The engineering } \\
\text { quality } \\
\text { requirements; ,14.1 } \\
\text { Materials, equipment } \\
\text { and engineering test } \\
\text { and inspection }\end{array}$ & $\begin{array}{c}5.1 \text { The quality } \\
\text { requirements, } 9.3 \\
\text { Materials, equipment and } \\
\text { engineering test and } \\
\text { inspection }\end{array}$ & & & $\sqrt{ }$ \\
\hline & $\begin{array}{c}\text { The developer } \\
\text { supply materials } \\
\text { and engineering } \\
\text { equipment delay } \\
\text { construction } \\
\text { schedule } \\
\end{array}$ & $R_{16}$ & $\begin{array}{c}5.2 \text { The developer supply } \\
\text { materials and equipment } \\
11.3 \text { The developer of } \\
\text { the delays }\end{array}$ & $\begin{array}{l}8.1 \text { The developer supply } \\
\text { materials and engineering } \\
\text { equipment }\end{array}$ & $\sqrt{ }$ & & \\
\hline & $\begin{array}{l}\text { Materials and } \\
\text { equipment is } \\
\text { unqualified by } \\
\text { contractor } \\
\end{array}$ & $R_{17}$ & $\begin{array}{l}5.4 \text { It is prohibited to } \\
\text { use unqualified } \\
\text { material and equipment }\end{array}$ & $\begin{array}{l}8.5 \text { It is prohibited to use } \\
\text { unqualified material and } \\
\text { equipment }\end{array}$ & $\sqrt{ }$ & & \\
\hline & $\begin{array}{l}\text { Benchmark data } \\
\text { error }\end{array}$ & $R_{18}$ & $\begin{array}{l}8.3 \text { The responsibility } \\
\text { of the benchmark data } \\
\text { error }\end{array}$ & $\begin{array}{l}\text { 7.5.1 Delays caused by } \\
\text { the reason }\end{array}$ & $\sqrt{ }$ & & \\
\hline & $\begin{array}{c}\text { delay by providing } \\
\text { drawings }\end{array}$ & $R_{19}$ & $\begin{array}{c}\text { 11.3 The delays of the } \\
\text { developer }\end{array}$ & $\begin{array}{c}\text { 7.5.1 The delays of the } \\
\text { developer }\end{array}$ & $\sqrt{ }$ & & \\
\hline & $\begin{array}{c}\text { delays in payment } \\
\text { of the contract } \\
\text { price }\end{array}$ & $R_{20}$ & $\begin{array}{l}11.3 \text { The delays caused } \\
\text { by contractor }\end{array}$ & $\begin{array}{c}\text { 2.6 Pay the contract } \\
\text { price, } 7.5 .1 \text { Delays caused } \\
\text { by the developer }\end{array}$ & $\sqrt{ }$ & & \\
\hline & $\begin{array}{l}\text { The employer } \\
\text { delays caused by } \\
\text { suspension of } \\
\text { construction }\end{array}$ & $R_{21}$ & $\begin{array}{l}11.3 \text { The delays caused } \\
\text { by contractor, } 12.2 \text { The } \\
\text { developer's } \\
\text { responsibility of } \\
\text { suspending }\end{array}$ & $\begin{array}{l}\text { 7.8.1 suspend } \\
\text { construction caused by } \\
\text { the developer }\end{array}$ & $\sqrt{ }$ & & \\
\hline \multirow{12}{*}{$\begin{array}{l}\text { Engineerin } \\
\quad \text { g risk }\end{array}$} & $\begin{array}{l}\text { Drawing is not in } \\
\text { conformity with } \\
\text { the contract }\end{array}$ & $R_{22}$ & 1.6.4 Error of drawings & $\begin{array}{l}\text { 7.15.1 The delays caused } \\
\text { by contractor }\end{array}$ & $\sqrt{ }$ & & \\
\hline & $\begin{array}{c}\text { Patent } \\
\text { infringement by } \\
\text { employer }\end{array}$ & $R_{23}$ & 1.11 Patent technology & $\begin{array}{l}\text { 1.11 Intellectual property } \\
\text { rights }\end{array}$ & $\sqrt{ }$ & & \\
\hline & $\begin{array}{l}\text { Client request } \\
\text { completed ahead } \\
\text { of schedule }\end{array}$ & $R_{24}$ & $\begin{array}{l}\text { 11.6 Time limit for a } \\
\text { project in advance }\end{array}$ & $\begin{array}{l}\text { 7.9 Completed ahead of } \\
\text { time }\end{array}$ & $\sqrt{ }$ & & \\
\hline & $\begin{array}{l}\text { Engineering } \\
\text { change }\end{array}$ & $R_{25}$ & $\begin{array}{l}\text { 15.3.2 Engineering } \\
\text { change }\end{array}$ & $\begin{array}{l}10.1 \text { The scope of } \\
\text { engineering change }\end{array}$ & $\sqrt{ }$ & & \\
\hline & $\begin{array}{l}\text { The developer } \\
\text { makes trial } \\
\text { operation failure }\end{array}$ & $R_{26}$ & 18.6 A test run & $\begin{array}{l}\text { 13.5 Operation during the } \\
\text { construction }\end{array}$ & $\sqrt{ }$ & & \\
\hline & $\begin{array}{l}\text { The contractor } \\
\text { infringement of } \\
\text { intellectual } \\
\text { property rights }\end{array}$ & $R_{27}$ & 1.11 Patent technology & $\begin{array}{l}1.11 \text { Intellectual property } \\
\text { rights }\end{array}$ & & & $\sqrt{ }$ \\
\hline & $\begin{array}{l}\text { The contractor to } \\
\text { replace } \\
\text { construction } \\
\text { equipment }\end{array}$ & $R_{28}$ & $\begin{array}{c}\text { 6.3 Require the } \\
\text { contractor to increase } \\
\text { or change of } \\
\text { construction equipment }\end{array}$ & $\begin{array}{c}\text { 8.8.3 Require the } \\
\text { contractor to increase or } \\
\text { change of construction } \\
\text { equipment }\end{array}$ & & & $\sqrt{ }$ \\
\hline & $\begin{array}{l}\text { road and bridge } \\
\text { temporary } \\
\text { reinforcement } \\
\end{array}$ & $R_{29}$ & $\begin{array}{c}7.4 \text { Oversize and } \\
\text { overweight parts } \\
\text { transportation } \\
\end{array}$ & $\begin{array}{c}\text { 1.10.4 Oversize and } \\
\text { overweight parts } \\
\text { transportation }\end{array}$ & & & $\sqrt{ }$ \\
\hline & $\begin{array}{l}\text { Delays caused by } \\
\text { contractor }\end{array}$ & $R_{30}$ & $\begin{array}{c}11.5 \text { Delays caused by } \\
\text { contractor }\end{array}$ & $\begin{array}{l}\text { 7.5.2 Delays caused by } \\
\text { contractor }\end{array}$ & & & $\sqrt{ }$ \\
\hline & $\begin{array}{l}\text { The contractor do } \\
\text { STH without } \\
\text { authorization } \\
\text { changes }\end{array}$ & $R_{31}$ & 15.2 Right to change & 10.2 Right to change & & & $\sqrt{ }$ \\
\hline & $\begin{array}{l}\text { The contractor } \\
\text { responsibility } \\
\text { make trial } \\
\text { operation failed } \\
\end{array}$ & $R_{32}$ & 18.7 A test run & $\begin{array}{l}\text { 13.5 Operation during the } \\
\text { construction }\end{array}$ & & & $\sqrt{ }$ \\
\hline & $\begin{array}{l}\text { The contractor } \\
\text { responsibilities of } \\
\text { transportation field } \\
\text { inside and outside } \\
\text { the public roads } \\
\text { and Bridges } \\
\end{array}$ & $R_{33}$ & $\begin{array}{c}7.5 \text { Responsibility for road } \\
\text { and bridge damage }\end{array}$ & $\begin{array}{l}1.10 .5 \text { Responsibility for } \\
\text { road and bridge damage }\end{array}$ & & & $\sqrt{ }$ \\
\hline
\end{tabular}




\begin{tabular}{|c|c|c|c|c|c|c|c|}
\hline \multirow{3}{*}{$\begin{array}{c}\text { form of the } \\
\text { risk }\end{array}$} & \multirow{3}{*}{ risk factors } & \multirow{3}{*}{$\begin{array}{c}\text { order } \\
\text { numbe } \\
\mathrm{r}\left(R_{i}\right)\end{array}$} & \multicolumn{2}{|c|}{ document name } & \multicolumn{3}{|c|}{ the subjects of liability } \\
\hline & & & \multirow{2}{*}{$\begin{array}{c}\text { 《Standard } \\
\text { construction of the } \\
\text { tender documents》 }\end{array}$} & \multirow{2}{*}{$\begin{array}{c}\langle\text { The project } \\
\text { construction } \\
\operatorname{contract}(\text { model text })\rangle\end{array}$} & \multicolumn{2}{|c|}{$\begin{array}{l}\text { The employer } \\
\text { responsibility }\end{array}$} & \multirow{2}{*}{$\begin{array}{c}\text { The } \\
\text { contractor } \\
\text { responsibi- } \\
\text { lity }\end{array}$} \\
\hline & & & & & interior & external & \\
\hline \multirow{3}{*}{$\begin{array}{l}\text { Engineerin } \\
\mathrm{g} \text { decision- } \\
\text { making risk }\end{array}$} & $\begin{array}{c}\text { Engineer indicate } \\
\text { error will increase } \\
\text { cost } \\
\end{array}$ & $R_{34}$ & $\begin{array}{l}\text { 3.4 Supervisor's } \\
\text { instructions }\end{array}$ & $\begin{array}{l}\text { 4.3 Supervisor's } \\
\text { instructions }\end{array}$ & $\sqrt{ }$ & & \\
\hline & $\begin{array}{c}\text { Delay of } \\
\text { commencement } \\
\text { notice } \\
\end{array}$ & $R_{35}$ & $\begin{array}{l}11.3 \text { The delays caused } \\
\text { by contractor }\end{array}$ & $\begin{array}{l}\text { 7.5.1 The delays caused } \\
\text { by contractor }\end{array}$ & $\sqrt{ }$ & & \\
\hline & $\begin{array}{c}\text { Instructions, } \\
\text { caused the delay } \\
\text { of the approval }\end{array}$ & $R_{36}$ & $\begin{array}{l}11.3 \text { The delays caused } \\
\text { by employer }\end{array}$ & $\begin{array}{l}\text { 7.5.1 The delays caused } \\
\text { by employer }\end{array}$ & $\sqrt{ }$ & & \\
\hline
\end{tabular}

This paper analyzes the 36 engineering project risk in the table 1.There are 14 engineering project risk that cannot change the contract status, and undertaked by the contractor. There are 4 internal engineering project risk that can change the contract status, and undertaked by the developer. There are 14 external engineering project risk undertaked by the developer. There are 4 engineering project risk undertaked by contracting people.

\section{The Key Points of State Compensation Contract}

When the risk happen by different patterns, the way of state compensation is different. The contract state compensation is a key mechanism to solve the dispute, and it can also cause project dispute. Because the environment of engineering contract is very complicated and the way of state compensation is various, I will explain how to make engineering change and adjust the price in engineering practice.

\subsection{The Key Node of Engineering Change}

Engineering change is an important work of contract management, and review and confirm of it is the most critical [10]. Contract price adjustment mainly includes two aspects in the process of engineering change. One is adjustment of sub-engineering fee, On the other hand is adjustment of measure fee. According to the actual workload to pay the contract price is a principle of adjusting sub-engineering fee. We should adjust the integrated unit price according to similar price, applicable price and other conventions. Adjust measure fee has three key points. The first key point is that Site safe and civilized construction should be calculated according to the contractual obligations. Meanwhile, it should abide by the contract and laws. The second key point is that we should calculate measure fee according to sub-engineering fee. The third key point is that we should make a distinction between unit price and total price.

\subsection{The Key Node of Price Adjustment}

Price adjustment is a way of adjusting the contract status. It happened when the price has been changed a lot in the contract. This article analyzed the relevant documents and management measures coming from Hubei province, Tianjin city and Qingdao city and so on. The results showed that the contractor may bear the price risk of main material, labor costs and mechanical cost, and the range of price change is $\pm 5 \% \sim \pm 10 \%, \pm 0 \% \sim \pm 5 \%, \pm 0 \% \sim \pm 5 \%$. When the area is not the same, range have tiny difference. When price changes over the range, the contracting parties shall compensate contract status.

\section{Summary}

This paper argues that the risk is a key factor causing the engineering project dispute based on the incomplete contract theory. The article explains the principle of the GHM theory through analyzing the research of state contract, and builded new model of state contract. In this paper, two key problems are solved. One is how to identification of risk factors and imputation. The other is how to confirm the key points of state compensation contract. In the process of analysis, research has identified 22 kinds of engineering project risk and confirm the key points of engineering change and price 
adjustment. At the same time, the article also explains the internal mechanism of dispute. Make a contribution to prevent project dispute in the future.

Although this study puts forward the solutions to prevent project dispute, there are still limitations to this study. For instance, this study did not determine the level of state contract, and did not give advice how to set the terms of the contract.

\section{References}

[1] Sun Yechun,Sun Fenghai. Engineering Project Risk Characteristics and Prevention [J].Journal of Shenyang Jianzhu University .2012,14(4):386-388.

[2] Xu Xixiong. The Contract Theory of the Reference Point: The Behavior of the Incomplete Contract theory and Experiment [J].Foreign economics \& management. 2012, 34 (11):52-54.

[3] Lv Wenxue,Zhang Lei,Bi Xing.Study on Decision of Construction Project Dispute Resolution Based on Fuzzy Cognitive Maps[J]. China Soft Science.2014.

[4] Yang Liming,Luo Ding. Model Construction Claims Related to the Engineering Contract Status[J].Construction Management Modernization.2006(86):41-42.

[5] Li Xiaolong,Zhang Shuli,Wang Libin.Engineering Contract Status and Control Model of Status Changing[J].journal of tongji university,2006(4):563-568.

[6] Yin Yilin, Wang Jianyun.Contract Status Analysis in the Application of Claim Management [J].Journal of Shenyang Jianzhu University ( Social Science ).2011.

[7] Li Kun,Zhou Xuefen. Contract Status, Time-varying System Evolution and FIDIC Contract Conditions State Interference Factor Analysis [J].Construction Economy. 2009(3):74-75.

[8] Nie Huihua, Yang Jing.The Challenges Encountered Property Rights Theory and Evolution, Based on the Latest Literature Since 2000[J]. Nankai Economic Studies. 2007(4):3-6.

[9] Yin Yilin,Xu Zhichao,Qiu Yan. Study on Countermeasures to Contractor's Opportunistic Behaviors in Public Project Based on Evolutionary Game Theory [J]. China Civil Engineering Journal. 2014,47(6):138-140.

[10] Li Weifang. Confirm and Control Engineering Change [J].Construction Economy. 2007(3): 2122. 